\title{
Pengaruh Perhatian Orang Tua dan Minat Belajar Siswa pada Pembelajaran Daring terhadap Hasil Belajar Matematika Kelas V SD Negeri Mangunrekso 01
}

\author{
Erlina Pujiningrum ${ }^{1}$, Joko Siswanto ${ }^{1}$, Sukamto ${ }^{1}$ \\ ${ }^{1}$ Program Studi Pendidikan Guru Sekolah Dasar, Fakultas Ilmu Pendidikan, \\ Universitas PGRI Semarang \\ Email : erlinashakaqueen26@gmail.com,jokosispgri@gmail.com, sukamto@upgris.ac.id
}

\begin{abstract}
Abstrak
Latar belakang penelitian ini adalah kurangnya minat belajar matematika, apalagi dengan adanya pembelajaran daring guru tidak menjelaskan materi kepada siswa. Selain itu orang tua tidak memperhatikan aktivitas belajar anak di rumah karena sebagian besar dari mereka sibuk bekerja di luar kota. Hal ini yang menyebabkan siswa kurang memperhatikan proses belajarnya dengan baik karena siswa tidak mendapatkan perhatian dari orang tuanya dan minat belajar siswa juga kurang sehingga hasil belajarnya rendah. Permasalahan dalam penelitian ini adalah 1) Apakah terdapat pengaruh perhatian orang tua pada pembelajaran daring terhadap hasil belajar matematika?, 2) Apakah terdapat pengaruh minat belajar siswa pada pembelajaran daring terhadap hasil belajar matematika?, 3) Apakah terdapat pengaruh perhatian orang tua dan minat belajar siswa pada pembelajaran daring secara bersama-sama terhadap hasil belajar matematika? Tujuan yang hendak dicapai dalam penelitian ini adalah untuk mengetahui pengaruh perhatian orang tua dan minat belajar siswa pada pembelajaran daring terhadap hasil belajar matematika kelas V SD Negeri Mangunrekso 01. Jenis penelitian ini adalah kuantitatif dengan metode $e x$ post facto. Populasi penelitian adalah semua siswa SD Negeri Mangunrekso 01. Sampel yang diambil adalah 29 siswa kelas V dengan menggunakan teknik purposive sampling. Data dalam penelitian ini diperoleh melalui angket, wawancara, dan dokumentasi. Hasil penelitian menunjukkan bahwa perhatian orang tua pada pembelajaran daring tidak berpengaruh signifikan terhadap hasil belajar matematika sebab nilai signifikan 0,234 $>0,05$, bila perhatian orang tua naik satu satuan maka hasil belajar matematika akan naik sebesar 9,4\%. Terdapat pengaruh minat belajar siswa pada pembelajaran daring secara signifikan terhadap hasil belajar matematika. Hal ini dibuktikan dengan nilai signifikan $0,026<0,05$. Kemudian terdapat pengaruh perhatian orang tua dan minat belajar siswa pada pembelajaran daring secara bersama-sama terhadap hasil belajar matematika kelas V SD Negeri Mangunrekso 01 dengan nilai signifikansi $0,006<0,05$ dan pengaruhnya sebesar 32,5\%.
\end{abstract}

Kata Kunci: Perhatian orang tua, minat belajar, pembelajaran daring, hasil belajar

\begin{abstract}
The background of this research is the lack of interest in learning mathematics, especially with the online learning of teachers do not explain the material to students. In addition, parents do not pay attention to children's learning activities at home because most of them are busy working outside the city. This causes students to pay less attention to the learning process because the students do not get attention from their parents and the interest in learning students is also lacking so that the learning outcomes are low. The problem in this study is 1) Is there any influence of parents' attention on online learning on the results of learning mathematics?, 2) Is there an influence of students' interest in online learning on the results of mathematics learning?, 3) Is there an influence of parents' attention and interest in learning students in online learning together on the results of learning mathematics? The purpose of this study was to find out the influence of parents' attention and students' interest in online learning on the results of learning mathematics grade V SD Negeri Mangunrekso 01. This type of research is quantitative with ex post facto method. The research population is all students of SD Negeri Mangunrekso 01. The samples were 29 grade $\mathrm{V}$ students using purposive sampling techniques. The data in this study was obtained through questionnaires, interviews, and documentation. The results showed that parents' attention to online learning has no significant effect on math learning outcomes because the score is significant $0.234>0.05$, if the attention of parents increases by one unit then the results of learning mathematics will increase by $9,4 \%$. There is asignificant influence on students' learning on online learning outcomes. This is evidenced by a significant value of $0.026<$ 0.05 . Then there is the influence of parents' attention and interest in learning students in online learning together on the results of learning mathematics grade V SD Negeri Mangunrekso 01 with a significance score of $0.006<$ 0.05 and its influence of $32,5 \%$.
\end{abstract}

Keywords: Parental attention, interest in learning, online learning, learning outcomes 


\section{PENDAHULUAN}

Pendidikan merupakan kewajiban dan hak yang seluruh warga negara Indonesia pantas mendapatkannya. Pendidikan di Indonesia memiliki tujuan guna membentuk karakter siswa menjadi individu yang bertanggung jawab dalam mencerdaskan kehidupan bangsa, berahlak mulia, mandiri, kreatif, beriman serta bertaqwa kepada Tuhan Yang Maha Esa, berpengetahuan dan menjadi warga negara yang demokratis (Sugiyono,2015:42). Dengan adanya virus COVID-19 kegiatan belajar dilaksanakan secara daring. Hal tersebut terdapat dalam Surat Edaran Menteri Pendidikan dan Kebudayaan Republik Indonesia Nomor 4 Tahun 2020 Tentang Pelaksanaan Kebijakan Pendidikan Dalam Masa Darurat Penyebaran COVID. Riyana (2018:14) mengatakan bahwa pembelajaran daring adalah sistem yang membantu siswa mempelajari pengetahuan yang lebih luas. Melalui prasarana yang tersedia oleh sistem, siswa mampu belajar kapanpun dan dimanapun tanpa dibatasi oleh waktu, jarak, dan ruang.

Melalui pembelajaran daring, siswa dapat belajar dimanapun dan bisa berinteraksi dengan guru melalui whatsapp group, classroom, zoom, dan video converence. Tetapi tidak semua siswa dapat mengikuti pembelajaran daring dengan baik. Hal tersebut dikarenakan adanya faktor lingkungan yang kurang mendukung untuk pembelajaran daring misalnya orang tua siswa yang tidak memiliki HP android, jaringan internet, dan minimnya perhatian orang tua dalam kegiatan belajar anak. Menurut Sadulloh Uyoh (2011: 188) mengatakan bahwa, lingkungan keluarga sebagai pendidikan utama serta pertama bagi anak karena peran keluarga untuk mendidik anak sangat berpengaruh terhadap keberhasilan pendidikan pada perkembangan anak selanjutnya. Keluarga disebut pendidikan pertama sebab dari keluargalah anak memperoleh pendidikan pertama kali sementara disebut pendidikan utama sebab anak memperoleh pendidikan dari masyarakat serta sekolah dengan tetap orang tualah yang memegang tanggung jawab pendidikannya, maka dari hal tersebut keluarga menjadi pihak yang berpengaruh dalam kehidupan anak. Sehingga, perlu adanya perhatian dari orang tua mengenai aktivitas belajarnya supaya anak memperoleh hasil belajar yang baik. Menurut Walgito (2005: 110) Perhatian adalah sebuah proses konsentrasi atau pemusatan semua kegiatan individu pada suatu objek atau sekelompok objek yang dituju. Proses ini merupakan sebuah cara dalam memusatkan fokus pada keseluruhan kegiatan yang dilaksanakan oleh individu. Menurut Mia (2017: 22) Perhatian orang tua ialah pendekatan orang tua yang berpusat pada anak dengan memberi contoh dan bimbingan yang menimbulkan dampak baik terhadap pendidikan anak.

Selain perhatian orang tua, hasil belajar siswa dipengaruhi dengan minat belajar. Slameto (2010: 180) mengemukakan, minat adalah sebuah aktivitas atau sesuatu yang disukai tanpa ada yang menyuruh. Semakin kuat ketertarikannya pada suatu yang terdapat dalam diri atau luar diri, maka minat yang dimiliki juga semakin besar. Oleh karenanya, minat tersebut muncul sebab terdapatnya perasaan senang dalam diri individu untuk mempelajari suatu hal yang ia sukai, jika seseorang tidak mempunyai minat, ia akan malas untuk mempelajari atau mengikuti proses belajar dengan baik. Dengan pengalaman belajar yang menyenangkan akan menimbulkan minat terhadap mata pelajaran tersebut, sehingga siswa terdorong untuk mempelajari berbagai ilmu yang ada dikurikulum sekolah sebab minat bisa memengaruhi capaian hasil belajar siswa dalam suatu mata pelajaran (Syah, 2012: 152).

Hasil belajar merupakan sebuah pencapaian yang didapat peserta didik melalui proses belajarnya. Guna melihat keberhasilan peserta didik dalam proses belajar, maka dilakukan evaluasi. Menurut Syah (dalam Muhammad Awal Nur, 2016:66) mengatakan, hasil belajar yakni ukuran kesuksesan peserta didik saat menyimak materi pelajaran yang diterima dari hasil tes suatu kompetensi tertentu atau materi pelajaran tertentu yang dinyatakan dalam bentuk angka. Menurut Rusman (2015: 67) hasil belajar merupakan suatu pengalaman yang didapatkan siswa dalam aspek pengetahuan, keterampilan, dan sikap. Menurut Wibowo (2015: 162) hasil belajar terdiri dua kata yaitu hasil yang berarti sesuatu yang diperoleh dari usahanya sedangkan belajar ialah langkah dalam perubahan perilaku siswa dari hasil interaksi dengan lingkungan dan melibatkan proses pengetahuan.

Berdasarkan hasil wawancara peneliti bersama guru kelas V SD Negeri Mangunrekso 01 di Kabupaten Pati, terdapat beberapa masalah yang ditemukan yaitu siswa kurang minat belajar matematika karena siswa menganggap matematika itu sulit apalagi dengan adanya pembelajaran daring guru tidak menjelaskan materi kepada siswa, jadi siswa diminta untuk belajar mandiri setelah itu guru memberikan tugas kepada siswa. Selama pembelajaran daring, guru kurang memanfaatkan sistem 
pembelajaran daring yang inovatif. Hal tersebut disebakan karena guru tidak menguasai teknologi sehingga guru hanya memberikan tugas melalui whatsapp group. Selain itu orang tua tidak memperhatikan aktivitas belajar anak di rumah karena sebagian besar dari mereka sibuk bekerja di luar kota dan tidak bisa bertemu anaknya di rumah. Dengan adanya pembelajaran daring saat ini, seharusnya orang tua yang memperhatikan kegiatan belajar anaknya di rumah agar anak merasa termotivasi selama pembelajaran daring. Untuk orang tua siswa yang tidak berada di rumah, maka siswa pasti merasa kesulitan karena tidak ada yang memberinya bimbingan selama pembelajaran daring. Hal ini yang menyebabkan siswa kurang memperhatikan proses belajarnya dengan baik karena siswa tidak mendapatkan perhatian dari orang tuanya dan minat belajar siswa juga kurang sehingga hasil belajarnya rendah.

Berdasarkan pemaparan tersebut, menjadikan ketertarikan peneliti guna meneliti tentang "Pengaruh Perhatian Orang Tua Dan Minat Belajar Siswa Pada Pembelajaran Daring Terhadap Hasil Belajar Matematika Kelas V SD Negeri Mangunrekso 01".

\section{METODE PENELITIAN}

Penelitian ini dilakukan di SD Negeri Mangunrekso 01. Pada penelitian ini, peneliti mengambil sampel dari kelas V yang memiliki siswa sebanyak 29 siswa. Metode yang digunakan dalam penelitian ini yaitu metode kuantitatif dengan penelitian ex post facto. Penelitian ex post facto merupakan metode penelitian yang merujuk pada tindakan atau manipulasi variabel bebas (X) yang sudah terjadi sebelumnya sehingga peneliti tidak perlu melakukan tindakan lebih lanjut, cukup melihat dampaknya terhadap variabel terikat (Y). (Nana Sudjana, 2017: 56).

Teknik pengumpulan data yang digunakan dalam penelitian ini yaitu angket, wawancara, dan dokumentasi. Teknik pengumpulan data berupa angket bertujuan untuk mendapatkan data tentang perhatian orang tua dan minat belajar siswa di SD Negeri Mangunrekso 01. Berikut kisi-kisi angket perhatian orang tua dan minat belajar pada pembelajaran daring :

Tabel 1. Kisi Kisi Angket Penelitian

\begin{tabular}{|c|c|c|c|}
\hline No & Aspek & Indikator & No Item Pernyataan \\
\hline \multirow[t]{4}{*}{1} & \multirow{4}{*}{$\begin{array}{l}\text { Perhatian Orang } \\
\text { Tua Dalam } \\
\text { Pembelajaran } \\
\text { Daring }\end{array}$} & $\begin{array}{l}\text { Memberi } \\
\text { kebebasan dalam } \\
\text { belajar }\end{array}$ & $1,2,3,4,5$ \\
\hline & & $\begin{array}{l}\text { Memberi } \\
\text { penghargaan atau } \\
\text { hukuman. }\end{array}$ & $6,7,8,9,10$ \\
\hline & & $\begin{array}{l}\text { Memberi } \\
\text { yang bontoh } \\
\text { anak. }\end{array}$ & $11,12,13,14,15$ \\
\hline & & $\begin{array}{l}\text { Membantu } \\
\text { mengatasi } \\
\text { kesulitan anak. }\end{array}$ & $16,17,18,19,20$ \\
\hline \multirow[t]{4}{*}{2} & \multirow{4}{*}{$\begin{array}{l}\text { Minat Belajar } \\
\text { Selama } \\
\text { Pembelajaran } \\
\text { Daring }\end{array}$} & Perasaan senang & $1,2,3,4,5$ \\
\hline & & Keterlibatan siswa & $6,7,8,9,10$ \\
\hline & & Ketertarikan & $11,12,13,14,15$ \\
\hline & & Perhatian siswa & $16,17,18,19,20$ \\
\hline
\end{tabular}

Sedangkan Wawancara digunakan untuk mendapatkan data relevan yang mendalam. Wawancara ini menggunakan wawancara terpimpin yaitu wawancara yang dilakukan terhadap pertanyaan-pertanyaan yang telah disiapkan sebelumnya (Iryana, 2019: 3). Berikut kisi-kisi pedoman wawancara :

Tabel 2. Kisi Kisi Pedoman Wawancara 


\begin{tabular}{|c|c|c|c|}
\hline No & Aspek & Indikator & Item Pertanyaan \\
\hline \multirow[t]{4}{*}{1} & \multirow[t]{4}{*}{$\begin{array}{l}\text { Perhatian } \\
\text { Orang Tua } \\
\text { Selama } \\
\text { Pembelajaran } \\
\text { Daring }\end{array}$} & $\begin{array}{l}\text { Memberi kebebasan } \\
\text { dalam belajar }\end{array}$ & $\begin{array}{l}\text { 1. Apakah orang tua } \\
\text { memberikan jadwal belajar } \\
\text { secara khusus selama } \\
\text { pembelajaran daring? } \\
\text { 2. Apakah orang tua } \\
\text { memberikan kebebasan } \\
\text { berkaitan jadwal belajar } \\
\text { selama pembelajaran daring } \\
\text { ? }\end{array}$ \\
\hline & & $\begin{array}{l}\text { Memberi } \\
\text { penghargaan atau } \\
\text { hukuman. }\end{array}$ & $\begin{array}{l}\text { 3. Apakah orang tua } \\
\text { memberikan hadiah jika anak } \\
\text { mendapatkan hasil belajar } \\
\text { yang memuaskan selama } \\
\text { pembelajaran daring? } \\
\text { 4. Apakah orang tua } \\
\text { memberikan hukuman jika } \\
\text { anak mendapatkan hasil } \\
\text { belajar yang kurang } \\
\text { memuaskan selama } \\
\text { pembelajaran daring? }\end{array}$ \\
\hline & & $\begin{array}{ll}\text { Memberi } & \text { contoh } \\
\text { yang baik kepada } \\
\text { anak. }\end{array}$ & $\begin{array}{l}\text { 5. Apakah orang tua } \\
\text { memberikan contoh sering } \\
\text { membaca buku terhadap anak } \\
\text { selama pembelajaran daring? }\end{array}$ \\
\hline & & $\begin{array}{l}\text { Membantu } \\
\text { mengatasi kesulitan } \\
\text { anak. }\end{array}$ & $\begin{array}{l}\text { 6. Apakah orang tua } \\
\text { mendampingi anak dalam } \\
\text { belajar selama pembelajaran } \\
\text { daring? } \\
\text { 7. Apakah orang tua membantu } \\
\text { anak jika mengalami } \\
\text { kesulitan mengerjakan tugas } \\
\text { selama pembelajaran daring? } \\
\text { 8. Apakah orang tua } \\
\text { memberikan fasilitas belajar } \\
\text { yang cukup selama } \\
\text { pembelajaran daring? }\end{array}$ \\
\hline \multirow[t]{4}{*}{2} & \multirow[t]{4}{*}{$\begin{array}{l}\text { Minat Belajar } \\
\text { Saat } \\
\text { Pembelajaran } \\
\text { Daring }\end{array}$} & Perasaan senang & $\begin{array}{l}\text { 9. Bagaimana perasaanmu } \\
\text { mengikuti pembelajaran } \\
\text { daring matematika di SD } \\
\text { Negeri Mangunrekso 01 ? }\end{array}$ \\
\hline & & Keterlibatan siswa & $\begin{array}{l}\text { 10. Apakah siswa aktif } \\
\text { mengikuti diskusi atau } \\
\text { senang menjawab kuis saat } \\
\text { mengikuti pembelajaran } \\
\text { daring matematika di SD } \\
\text { Negeri Mangunrekso } 01 \text { ? }\end{array}$ \\
\hline & & Ketertarikan & $\begin{array}{l}\text { 11. Apakah siswa tertarik } \\
\text { mengikuti pembelajaran } \\
\text { daring matematika di SD } \\
\text { Negeri Mangunrekso 01 ? }\end{array}$ \\
\hline & & Perhatian siswa & $\begin{array}{l}\text { 12. Apakah siswa fokus ketika } \\
\text { mengikuti pembelajaran } \\
\text { daring matematika di SD } \\
\text { Negeri Mangunrekso } 01 \text { ? }\end{array}$ \\
\hline
\end{tabular}

Hal. 4 
Kemudian pengumpulan data melalui dokumentasi diperlukan guna mengumpulkan data yang terkait dengan penelitian tentang sekolah yang diteliti. Untuk teknik analisis data yang digunakan adalah uji asumsi klasik berupa uji normalitas, uji multikolinearitas, uji heteroskedastisitas dan analisis regresi berganda. Sedangkan untuk pengujian hipotesis menggunakan uji-t, uji-f, uji koefisien determinasi. Sebelum melakukan uji asumsi klasik dan uji hipotesis, terlebih dahulu dilakukan pengujian instrumen. Berikut hasil pengujian instrumen :

Tabel 3. Rekapitulasi Hasil Uji Validitas Angket Perhatian Orang Tua dan Minat Belajar Siswa Pada Pembelajaran Daring

\begin{tabular}{|c|c|c|c|}
\hline $\begin{array}{c}\text { Nomor } \\
\text { Item Soal }\end{array}$ & $\mathbf{R}_{\text {hitung }}$ & $\mathbf{R}_{\text {table }}$ & Keterangan \\
\hline 1 & 0,015 & 0,367 & Tidak Valid \\
\hline 2 & 0,385 & 0,367 & Valid \\
\hline 3 & 0,418 & 0,367 & Valid \\
\hline 4 & 0,617 & 0,367 & Valid \\
\hline 5 & 0,453 & 0,367 & Valid \\
\hline 6 & 0,526 & 0,367 & Valid \\
\hline 7 & 0,539 & 0,367 & Valid \\
\hline 8 & 0,437 & 0,367 & Valid \\
\hline 9 & 0,071 & 0,367 & Tidak Valid \\
\hline 10 & 0,544 & 0,367 & Valid \\
\hline 11 & 0,744 & 0,367 & Valid \\
\hline 12 & 0,373 & 0,367 & Valid \\
\hline 13 & 0,478 & 0,367 & Valid \\
\hline 14 & 0,120 & 0,367 & Tidak Valid \\
\hline 15 & 0,600 & 0,367 & Valid \\
\hline 16 & 0,191 & 0,367 & Tidak Valid \\
\hline 17 & 0,541 & 0,367 & Valid \\
\hline 18 & 0,611 & 0,367 & Valid \\
\hline 19 & 0,447 & 0,367 & Valid \\
\hline 20 & 0,611 & 0,367 & Valid \\
\hline 1 & 0,693 & 0,367 & Valid \\
\hline 2 & 0,649 & 0,367 & Valid \\
\hline 3 & 0,659 & 0,367 & Valid \\
\hline 4 & 0,497 & 0,367 & Valid \\
\hline 5 & 0,777 & 0,367 & Valid \\
\hline 6 & 0,520 & 0,367 & Valid \\
\hline 7 & 0,556 & 0,367 & Valid \\
\hline 8 & 0,349 & 0,367 & Tidak Valid \\
\hline 9 & 0,722 & 0,367 & Valid \\
\hline 10 & 0,525 & 0,367 & Valid \\
\hline 11 & 0,555 & 0,367 & Valid \\
\hline 12 & 0,553 & 0,367 & Valid \\
\hline 13 & 0,622 & 0,367 & Valid \\
\hline 14 & 0,708 & 0,367 & Valid \\
\hline 15 & 0,770 & 0,367 & Valid \\
\hline 16 & 0,624 & 0,367 & Valid \\
\hline 17 & 0,467 & 0,367 & Valid \\
\hline 18 & 0,514 & 0,367 & Valid \\
\hline 19 & 0,467 & 0,367 & Valid \\
\hline 20 & 0,602 & 0,367 & Valid \\
\hline
\end{tabular}

Tabel 4. Rekapitulasi Hasil Uji Reliabilitas Angket Perhatian Orang Tua dan Minat Belajar Siswa Pada Pembelajaran Daring 


\begin{tabular}{ccc}
\hline Variabel & Hasil Nilai Cronbach's Alpha & Keterangan \\
\hline Perhatian Orang Tua & 0,820 & Reliabel \\
Minat Belajar & 0,902 & Reliabel \\
\hline
\end{tabular}

\section{HASIL DAN PEMBAHASAN}

Setelah data hasil penelitian diperoleh, selanjutnya dilakukan uji normalitas untuk mengetahui data berdistribusi normal atau tidak (Ghozali, 2012:160). Uji normalitas menggunakan probability plot. Dalam uji normalitas, pengambilan keputusannya yaitu :

1. Bila data tersebar di sekitar garis diagonal dan mengikuti arah garis diagonal maka pola tersebut berdistribusi normal, jadi model regresi memenuhi asumsi normalitas.

2. Bila data tersebar menjauhi garis diagonal atau tidak mengikuti arah garis diagonal maka pola tersebut tidak berdistribusi normal, jadi model regresi tidak memenuhi asumsi normalitas. Berikut hasil uji normalitas menggunakan probability plot :

Normal P-P Plot of Regression Standardized Residual

\section{Dependent Variable: Hasil Belajar $(Y)$}

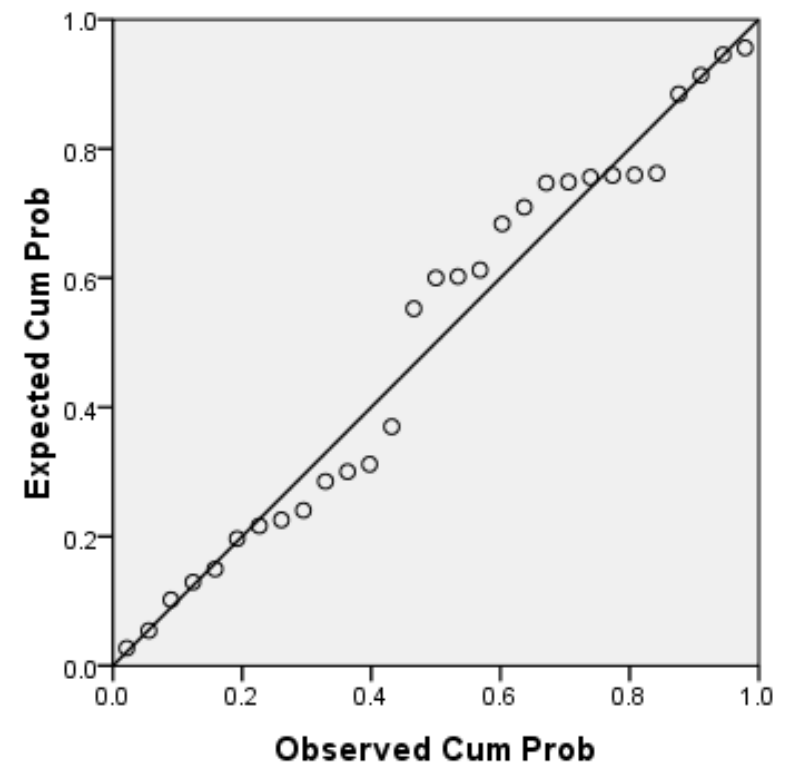

Gambar 1. Uji Normalitas (Sumber SPSS 16)

Dari gambar diatas dapat disimpulkan bahwa titik-titik ploting pada gambar Normal P-P Plot of Regression Standardized Residual mengikuti arah garis diagonal dan tersebar disekitar garis diagonal, jadi model regresi memenuhi asumsi normalitas. Untuk lebih meyakinkan hasil dari normal P P-Plot, peneliti melakukan uji normalitas Kolmogorov Smirnov dengan pengambilan keputusannya yaitu :

1. Bila nilai signifikansi Asiymp.Sig (2-tailed) lebih besar dari 0,05 jadi data penelitian berdistribusi normal.

2. Bila nilai signifikansi Asiymp.Sig (2-tailed) lebih kecil dari 0,05 jadi data tidak berdistribusi normal. 


\begin{tabular}{|ll|r|}
\hline & & $\begin{array}{c}\text { Unstandardized } \\
\text { Residual }\end{array}$ \\
\hline $\mathrm{N}$ & & 29 \\
Normal Parameters $^{\mathrm{a}}$ & Mean & .0000000 \\
& Std. Deviation & 6.07314867 \\
Most Extreme Differences & Absolute & .121 \\
& Positive & .109 \\
& Negative & -.121 \\
Kolmogorov-Smirnov Z & & .652 \\
Asymp. Sig. (2-tailed) & & .789 \\
\hline
\end{tabular}

Dari tabel diatas diperoleh nilai Asymp.Sig (2-tailed) 0,789 jadi nilai signifikansi Asiymp.Sig (2tailed) lebih besar dari 0,05 maka data berdistribusi normal.

Selanjutnya dilakukan uji multikolinearitas guna menguji model regresi terdapat korelasi antara variabel independen (bebas) atau tidak. Jika tidak ada korelasi antara variabel independen maka model regresi dikatakan baik. Salah satu cara untuk mendeteksi multikoliniearitas dalam model regresi ialah melihat nilai toleransi dan nilai Variance Inflation Factor (VIF). Jika nilai tolerance > 0,10 atau nilai VIF $<10$, hal ini menunjukkan bahwa model regresi tidak terdapat multikolinieritas (Ghozali, 2012:110).Berikut hasil uji multikolinearitas :

Tabel 6. Rekapitulasi Hasil Uji Multikolinearitas

\begin{tabular}{lcccc}
\hline \multirow{2}{*}{ Variabel } & \multicolumn{2}{c}{ Collinearity Statistics } & \multirow{2}{*}{ Keterangan } \\
\cline { 2 - 3 } & Tolerance & VIF & Tidak terdapat \\
Perhatian Orang Tua $\left(\mathrm{X}_{1}\right)$ & 0,780 & 1,283 & & multikolinearitas \\
Minat Belajar $\left(\mathrm{X}_{2}\right)$ & 0,780 & 1,283 & & $\begin{array}{c}\text { Tidak terdapat } \\
\text { multikolinearitas }\end{array}$ \\
\hline
\end{tabular}

Kemudian dilakukan uji heteroskedastisitas guna menguji model regresi terdapat ketidaksamaan variasi dari residual satu pengamat ke pengamat lainnya atau tidak. Bila variasi dari residual satu pengamat ke pengamat lain tetap, maka disebut homoskedastisitas dan jika berbeda disebut heteroskedastisitas. Model regresi yang baik, bila model regresi tidak terdapat heteroskedastisitas karena data ini menghimpun data yang mewakili berbagai ukuran (Ghozali,2012: 139). Pengambilan keputusan uji heteroskedastisitas menggunakan uji glejser yaitu :

1. Bila nilai signifikansi (Sig.) lebih besar dari 0,05 jadi model regresi tidak terdapat heteroskedastisitas.

2. Bila nilai signifikansi (Sig.) lebih kecil dari 0,05 jadi model regresi terdapat heteroskedastisitas.

Dari tabel diperoleh nilai sig. 0,149 pada variabel perhatian orang tua (X1) dan nilai sig. 0,302 pada variabel minat belajar (X2), jadi nilai signifikansi lebih besar dari 0,05 maka model regresi tidak terdapat heteroskedastisitas.

Setelah melakukan uji prasyarat, selanjutnya dilakukan uji hipotesis menggunakan regresi linier berganda yang bertujuan guna menguji pengaruh dua atau lebih variabel independen terhadap variabel dependen. Berikut hasil analisis datanya: 
Tabel 7. Uji Regresi Linear Berganda

\begin{tabular}{lccc}
\hline \multicolumn{1}{c}{ Variabel } & Koefisien Regresi & $\mathrm{t}_{\text {hitung }}$ & Sig. \\
\hline Konstanta & 33,205 & 3,001 & 0,006 \\
$\mathrm{X}_{1}$ & 0,188 & 1,218 & 0,234 \\
$\mathrm{X}_{2}$ & 0,306 & 2,364 & 0,026 \\
\hline
\end{tabular}

Dari hasil analisis regresi linear berganda diperoleh persamaan $Y ́=33,205+0,188 \mathrm{X}_{1}+0,306 \mathrm{X}_{2}$ persamaan tersebut menunjukkan bahwa a $=33,205$ jadi nilai konsistensi hasil belajar matematika sebesar 33,205 bila tidak terdapat perhatian orang $\left(\mathrm{X}_{1}\right)$ dan minat belajar $\left(\mathrm{X}_{2}\right)$. Kemudian diketahui nilai koefisien perhatian orang tua $\left(\mathrm{X}_{1}\right)$ sebesar 0,188 . Bila terdapat kenaikan perhatian orang tua pada pembelajaran daring sebesar 1 satuan variabel mengakibatkan kenaikan hasil belajar matematika sebesar 0,188 dengan nilai signifikan 0,234>0,05 jadi tidak terdapat korelasi antara perhatian orang tua pada pembelajaran daring terhadap hasil belajar matematika. Sedangkan nilai koefisien minat belajar sebesar 0,306, bila ada peningkatan minat belajar siswa pada pembelajaran daring sebesar 1 satuan variabel akan mengakibatkan peningkatan hasil belajar matematika senilai 0,306 . Nilai koefisien bersifat positif dengan signifikan $0,026<0,05$ maka terdapat korelasi positif antara minat belajar pada pembelajaran daring terhadap hasil belajar matematika.

Tabel 8. Uji-t

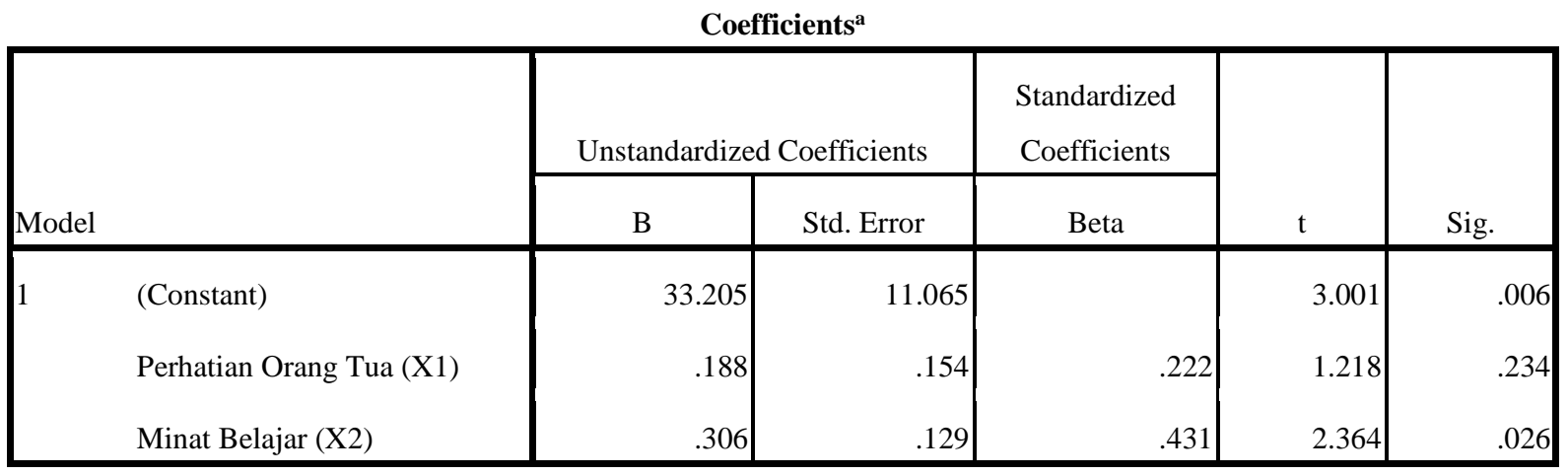

a. Dependent Variable: Hasil Belajar (Y)

Dari tabel diatas, dapat melihat pengaruh perhatian orang tua dan minat belajar pada pembelajaran daring secara parsial atau sendiri-sendiri terhadap hasil belajar. Untuk pengambilan keputusannya yaitu :

1. Bila nilai signifikan $>0,05$ maka Ho diterima dan Ha ditolak, jadi tidak terdapat pengaruh antar variabel yang diuji.

2. Bila nilai signifikan $<0,05$ maka Ho ditolak dan Ha diterima, jadi terdapat pengaruh antar variabel yang diuji.

Berdasarkan pengujian hipotesis, perhatian orang tua diperoleh nilai signifikan 0,234 jadi nilai signifikan lebih besar dari 0,05 maka tidak terdapat pengaruh perhatian orang tua pada pembelajaran daring secara signifikan terhadap hasil belajar matematika siswa kelas V SD Negeri Mangunrekso 01. Dari hasil penelitian menyatakan bahwa banyak siswa yang menjawab sangat setuju dan setuju pada angket perhatian orang tua pada pembelajaran daring terhadap hasil belajar matematika, Maka 77,4\% siswa mendapatkan perhatian orang tua pada pembelajaran daring tetapi dari hasil belajar matematika selama pembelajaran daring, 50\% siswa memperoleh nilai rendah. Bentuk perhatian yang diberikan orang tua $45,3 \%$ yaitu memberi contoh yang baik pada anak.

Dari hasil wawancara dengan guru kelas, orang tua kurang memberikan bimbingan belajar secara langsung sebab orang tua bekerja di luar kota dan mereka menyerahkan anak sepenuhnya kepada pihak sekolah. Jadi tinggi rendahnya perhatian orang tua yang diberikan tidak berpengaruh terhadap hasil belajar matematika siswa. Tetapi bila orang tua memberikan perhatian dengan sungguh-sungguh dan siswa mendapatkan dorongan untuk belajar, maka akan menimbulkan minat siswa pada pelajaran matematika sehingga hasil belajarnya naik sebesar $9,4 \%$. 
Hasil penelitian ini sejalan dengan penelitian yang dilakukan Santy Handayani (2016) bahwa perhatian orang tua tidak memberi pengaruh secara signifikan pada prestasi belajar matematika. Sedangkan pada variabel minat belajar diperoleh nilai signifikan 0,026 jadi nilai signifikan lebih kecil dari 0,05 maka terdapat pengaruh minat belajar siswa pada pembelajaran daring secara signifikan terhadap hasil belajar matematika kelas V SD Negeri Mangunrekso 01 sebesar 23,1\% karena diketahui beta 0,431 dan koefisien korelasinya 0,536. Dari hasil penelitian tersebut, $40 \%$ siswa suka dengan pembelajaran daring tetapi $82 \%$ mereka tidak menyukai pelajaran matematika dan menganggap matematika sulit apalagi selama pembelajaran daring guru tidak menjelaskan materi sehingga hasil belajar siswa rendah. Hal ini sesuai dengan pendapat Ormrod (2008: 101) menjelaskan bahwa siswa yang mengerjakan suatu tugas yang dapat menarik minatnya akan menimbulkan efek baik pada dirinya seperti rasa senang, suka, dan gembira ketika mengikuti pembelajaran. Menurut Usman (2010:27) menjelaskan bahwa minat ialah suatu perasaan yang melekat dalam diri seseorang. Minat mempunyai dampak yang sangat tinggi mengenai kegiatan belajar karena dengan adanya minat, orang yang tertarik hendak menjalankan sesuatu, apabila minat tidak dimiliki seseorang, maka ia tidak akan melakukan sesuatu. Hasil penelitian ini sejalan dengan penelitian dari Andi Eliyah (2016) bahwa ada pengaruh positif antara minat belajar siswa dengan prestasi belajar IPS dan hasil penelitian dari Santy Handayani (2016) bahwa minat belajar siswa memberi pengaruh secara signifikan pada prestasi belajar matematika.

Tabel 9. Uji F

\section{ANOVA $^{b}$}

\begin{tabular}{|c|c|c|c|c|c|c|}
\hline \multicolumn{2}{|c|}{ Model } & Sum of Squares & Df & Mean Square & $\mathrm{F}$ & Sig. \\
\hline \multirow[t]{3}{*}{1} & Regression & 497.962 & 2 & 248.981 & 6.268 & $.006^{\mathrm{a}}$ \\
\hline & Residual & 1032.728 & 26 & 39.720 & & \\
\hline & Total & 1530.690 & 28 & & & \\
\hline
\end{tabular}

a. Predictors: (Constant), Minat Belajar (X2), Perhatian Orang Tua (X1)

b. Dependent Variable: Hasil Belajar (Y)

Berdasarkan tabel diatas, dapat menentukan pengaruh perhatian orang tua dan minat belajar siswa pada pembelajaran daring secara bersama-sama terhadap hasil belajar. Dari hasil pengujian hipotesis diperoleh nilai signifikan 0,006, jadi nilai signifikan lebih kecil dari 0,05 maka terdapat pengaruh perhatian orang tua dan minat belajar siswa pada pembelajaran daring secara bersama-sama terhadap hasil belajar matematika kelas V SD Negeri Mangunrekso 01 sebesar 32,5\%. Hal ini sesuai dengan pendapat menurut Mia (2017: 22) menjelaskan bahwa perhatian orang tua yaitu pendekatan orang tua yang berpusat pada anak dengan memberikan contoh dan bimbingan yang menimbulkan dampak baik terhadap pendidikan anak. Jadi siswa akan merasa nyaman dan aman serta bahagia dalam mengikuti pembelajaran karena mendapatkan perhatian dari orang tua. Perasaan yang dirasakan siswa karena perhatian orang tua akan mendorong kemauannya untuk belajar, dorongan atau keinginan ini dinamakan minat belajar. Melalui minat tersebut, siswa akan merasa senang hati melaksanakan aktivitas belajar dan penuh kemauan untuk belajar tanpa ada paksaan. Keadaan tersebut memungkinkan siswa untuk bersungguh-sungguh mempelajari matematika sehingga siswa bisa mendapatkan hasil belajar yang baik. Hasil penelitian ini sejalan dengan hasil penelitian dari Andi Eliyah (2016) bahwa terdapat pengaruh positif secara bersama - sama antara perhatian orang tua dan minat belajar IPS dengan prestasi belajar IPS dan hasil penelitian dari Noor Komari Pratiwi (2015) menyatakan bahwa ada pengaruh pada tingkat pendidikan, perhatian orang tua, dan minat belajar siswa terhadap prestasi belajar Bahasa Indonesia. 
Tabel 10. Koefisien Determinasi

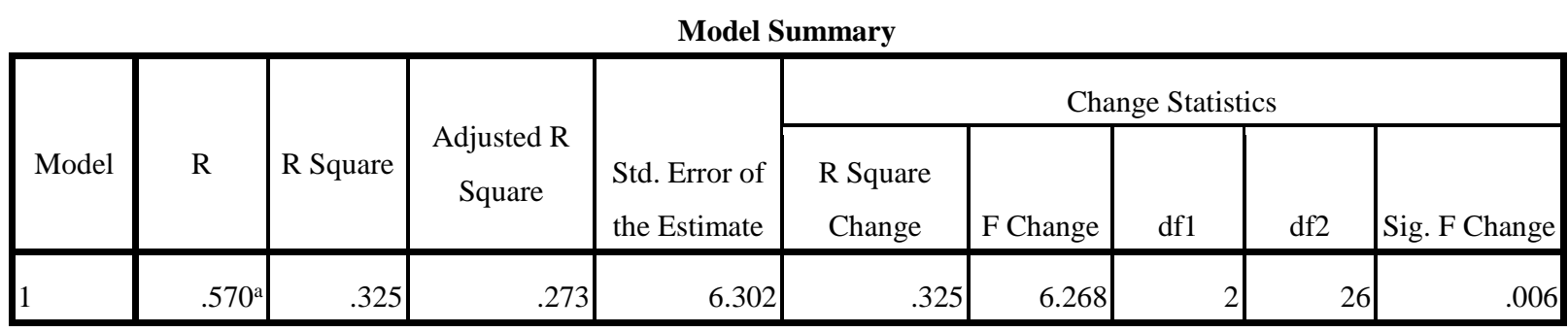

a. Predictors: (Constant), Minat Belajar (X2), Perhatian Orang Tua (X1)

Dari hasil uji hipotesis tersebut diperoleh koefisien korelasi sebesar 0,570 dan koefisien determinasi sebesar 0,325. Maka besarnya pengaruh perhatian orang tua dan minat belajar siswa pada pembelajaran daring secara bersama-sama terhadap hasil belajar matematika kelas V SD Negeri Mangunrekso 01 sebesar 32,5\% dan sisanya $100 \%-32,5 \%=67,5 \%$ dipengaruhi dari variabel residu diluar variabel yang diteliti. Nilai R Square sebesar 0,325 jadi pengaruh variabel perhatian orang tua dan minat belajar secara bersama-sama terhadap variabel hasil belajar lemah. Nilai R Square rendah karena ada satu variabel $\mathrm{X}$ yang tidak berpengaruh signifikan terhadap variabel $\mathrm{Y}$ yaitu variabel perhatian orang tua. Berdasarkan nilai signifikansi $\mathrm{F}$ change, nilai $0,006<0,05$ maka variabel perhatian orang tua dan minat belajar secara bersama-sama terdapat korelasi terhadap variabel hasil belajar. Untuk melihat keeratan hubungannya, dapat dilihat pada nilai $\mathrm{R}$ yaitu 0,570 . Menurut referensi Wiratna Sujarweni, keeratan hubungan tersebut termasuk dalam korelasi sedang.

\section{PENUTUP}

\section{Simpulan}

Berdasarkan pengujian hipotesis diperoleh informasi bahwa nilai sig $=0,234$ lebih besar dari 0,05 jadi perhatian orang tua pada pembelajaran daring tidak berpengaruh secara signifikan terhadap hasil belajar matematika siswa kelas V SD Negeri Mangunrekso 01. Bila terdapat kenaikan perhatian orang tua pada pembelajaran daring sebesar 1 satuan variabel perhatian orang tua maka mengakibatkan kenaikan hasil belajar matematika sebesar 9,4\% dengan asumsi tidak ada variabel lain yang diteliti. Kemudian terdapat pengaruh minat belajar siswa pada pembelajaran daring secara signifikan terhadap hasil belajar matematika kelas V SD Negeri Mangunrekso 01 sebesar 23,1\% dengan nilai sig $=0,026$ lebih kecil dari 0,05 . Terdapat pengaruh sebesar 32,5\% perhatian orang tua dan minat belajar siswa pada pembelajaran daring secara bersama-sama terhadap hasil belajar matematika kelas V SD Negeri Mangunrekso 01 dengan nilai signifikan 0,006.

\section{Saran}

Berdasarkan hasil penelitian, maka saran yang dapat dilakukan untuk meningkatkan hasil belajar matematika pada pembelajaran daring yaitu guru sebaiknya memberikan pembelajaran yang inovatif supaya siswa merasa tertarik untuk belajar, kemudian memberikan nasihat kepada orang tua yang kurang memperhatikan aktivitas belajar anaknya di rumah, meskipun perhatian orang tua tidak berpengaruh terhadap hasil belajar tetapi jika dilakukan dengan baik, anak akan merasa terdorong untuk belajar dengan sungguh-sungguh sehingga akan mengakibatkan perubahan pada hasil belajarnya. Selain itu, memberikan informasi pada siswa bahwa pentingnya meningkatkan belajar pada pembelajaran daring karena pengetahuan bisa diperoleh dari mana saja, apabila guru tidak memberikan penjelasan materi, maka dapat melihat dari youtube supaya hasil belajar matematika pada pembelajaran daring tetap baik.

\section{DAFTAR PUSTAKA}

Ahmadi, Abu dan Supriyono Widodo. 2013. Psikologi Belajar. Jakarta: PT Rineka Cipta.

Dimyati dan Mudjiono. 2009. Belajar dan Pembelajaran. Jakarta: Rineka Cipta.

Djamarah, Syaiful Bahri. 2002. Psikologi Belajar. Jakarta: PT Rineka Cipta. 
Fausi, Mia Rizky. 2017. "Pengaruh Perhatian Orang Tua, Disiplin Belajar, Dan Motivasi Belajar Terhadap Prestasi Belajar Akuntansi Siswa Kelas XI IPS SMA Negeri 1 Depok Tahun Ajaran 2016/2017”. Skripsi. Yogyakarta: http://journal.student.uny.ac.id/ojs/index.php/kpai/article/view/9881/0.

Ghozali, Imam. 2012. Aplikasi Analisis Multivariate dengan Program IBM SPSS. Semarang: Universitas Diponegoro.

Handayani, Santy. 2016. "Pengaruh Perhatian Orang Tua Dan Minat Belajar Matematika Terhadap Prestasi Belajar Matematika Siswa”. Jurnal Formatif. 6 (2): 141 - 148. Universitas Indraprasta PGRI.

http://digilib.mercubuana.ac.id/manager/t!@file_artikel_abstrak/Isi_Artikel_218046793096.pdf

Janie, Dyah Nirmala. 2012. Statistik Deskriptip Dan Regresi Linier Berganda Dengan SPSS. Semarang: Semarang University Press.

Khaeriyah, Siti, Sukamto, Mei Fita Asri Untari. 2018. "Pengaruh Pendekatan Realistic Mathematic Education Terhadap Hasil Belajar Matematika". Jurnal Sinektik. Universitas Slamet Riyadi. Volume 1 Nomor 1. http://ejurnal.unisri.ac.id/index.php/sin/article/view/2290/2045.

Nur, Muhammad Awal. 2016. "Pengaruh Perhatian Orang Tua, Konsep Diri, Persepsi Tentang Matematika Terhadap Hasil Belajar Matematika Melalui Motivasi Belajar Siswa Kelas VIII SMP Negeri Di Kecamatan Ujung Loe Kabupaten Bulukumba". Jurnal Matematika dan Pembelajarannya. STMIK Bina Adinata Bulukumba. Volume 2 No. 2. https://jurnal.iainambon.ac.id/index.php/INT/article/viewFile/288/221.

Ormrod, Jeanne Ellis. 2018. Psikologi Pendidikan Membantu Siswa Tumbuh dan Berkembang. Jakarta: PT Erlangga.

Pratiwi, Noor Komari. 2015. "Pengaruh Tingkat Pendidikan, Perhatian Orang Tua, Dan Minat Belajar Siswa Terhadap Prestasi Belajar Bahasa Indonesia Siswa SMK Kesehatan Di Kota Tangerang”. Jurnal Pujangga. Universitas Indraprasta PGRI. Volume 1 Nomor 2. http://journal.unas.ac.id/pujangga/article/view/320/218.

Riyana, Cepi. 2018. Konsep Pembelajaran Online. Jakarta: Universitas Terbuka Press.

Slameto. 2010. Belajar dan Faktor-Faktor yang Mempengaruhinya. Jakarta: Rineka Cipta.

Soraya, Tria Alfi, Joko Siswanto, Veryliana Purnamasari. 2018. "Keefektifan Media Miniatur Rumah Pada Pembelajaran Number Heads Together Terhadap Hasil Belajar Siswa Pada Pembelajaran Matematika Di Kelas V SD”. Jurnal Handayani. Universitas Negeri Medan. Volume 9 Nomor 1. https://jurnal.unimed.ac.id/2012/index.php/handayani/article/view/10579/9485.

Sudjana, Nana. 2017. Penilaian Hasil Proses Belajar Mengajar. Bandung: PT Remaja Rosdakarya.

Sugiyono. 2015. Penelitian Kualitatif, Kuantitatif, RnD. Bandung: Alfabeta.

Usman, Moh. Uzer. 2010. Menjadi Guru Profesional. Bandung: PT Remaja Rosdakarya.

Walgito. 2010. Psikologi Pengantar Umum. Yogyakarta: Penerbit Andi. 